\title{
THE IMPLEMENTATION OF INDUCTIVE MODEL IN THE LEARNING OF FINDING RELIGIOUS VALUES IN SHORT STORIES "ROBOHNYA SURAU KAMI" BY A.A. NAVIS
}

\author{
Nendah Siti Nurfuadah \\ Universitas Suryakancana, Cianjur \\ e-mail:nendahnn@yahoo.com
}

\begin{abstract}
This article reveals the effectiveness of using inductive learning models to find religious values in the short story. The method used in the study is PTK. The experiment was conducted in three cycles, each cycle consists of two meetings. The study was conducted in grade XI MAN Cianjur. The results showed that inductive models can enhance the learning process, especially the attention of students in learning and students cooperation in group discussions. In the first cycle, in terms of students attention, from 44 students there are 29 students $(65.90 \%)$ paid attention, and in terms of cooperation of the students in group discussions, there were 27 students (61.36\%) are cooperative. In the second cycle, from 44 students there were 33 students (75\%) who paid attention, and regarding the cooperation of the group, there are 30 students (68.18\%) who are cooperative. In the third cycle, from 44 students there are 38 students $(86.36 \%)$ who paid attention, and regarding group cooperation there are 39 students (88.64\%)who are cooperative. The student' results in the first cycle obtained an average value of 68.64, in the second cycle the average value was 77.16, and in the third cycle the average value was 91.82. Therefore, it is concluded that the implementation of inductive learning model on learning of finding religious values on the short story in class XI MAN Cianjur can enhance the learning process and student learning outcomes.
\end{abstract}

Keywords: religious value, inductive models, processes and outcomes of learning

\section{PENDAHULUAN}

Nilai-nilai kehidupan bisa diperoleh dari berbagai hal, salah satunya dari karya sastra. Sebuah karya sastra yang bermutu ialah karya yang bermanfaat dan mengandung model kehidupan disertai dengan nilai-nilai atau pesan-pesan yang ingin disampaikan pengarang kepada pembacanya.

Cerpen adalah karya sastra berbentuk prosa yang dapat diambil manfaat dan dapat dijadikan bahan ajar. Nilai yang sering ditemukan dalam cerpen adalah nilai religi, hal ini didasarkan pada realitas kehidupan bahwa hampir semua pengarang adalah seorang yang beragama atau religius. Oleh karena itu, sebagai seseorang yang beragama (religiusitas), pastilah pengarang memasukkan unsur religi ke dalam karya sastranya.
Di sekolah kerap kali jika pembelajaran sastra, hanya menganalisis unsur pembangunnya saja seperti unsur intrinsik, tetapi bila dikaji dan diteliti lebih mendalam, tidak hanya akan menemukan unsur pembangunnya saja tetapi nilai kehidupan yang terkandung dalam sastra yang bermanfaat kepada pembacanya. Pembelajaran sastra di sekolah sangatlah penting karena melalui karya sastra, siswa dapat menggali nilai-nilai yang terkandung di dalamnya untuk pembentukan watak, sikap, moral, dan kepribadian siswa dalam kehidupan sehari-hari. Dengan demikian, pembelajaran sastra di sekolah adalah untuk menanamkan dan menumbuhkan rasa peka terhadap karya sastra. Melatih kepekaan rasa dan menstabilkan emosi, karena sastra menyuguhkan fakta dari nilai-nilai kehidupan dengan 
berbagai fenomena yang berhubungan erat dengan proses berpikir rasional.

Salah satu yang dihadapi dunia pendidikan di Indonesia adalah masalah lemahnya proses pembelajaran. Dalam proses pembelajaran, siswa kurang didorong untuk mengembangkan kemampuan berpikir. Sanjaya (2010:1) mengemukakan proses pembelajaran di dalam kelas diarahkan kepada kemampuan siswa untuk menghafal informasi; otak siswa dipaksa untuk mengingat dan menimbun berbagai informasi tanpa dituntut untuk memahami informasi yang diingatnya itu untuk menghubungkannya dengan kehidupan sehari-hari.

Dalam suatu pembelajaran terdapat model pembelajaran yang digunakan guru untuk mentrasfer informasi kepada siswa. Dikemukakan oleh Aunurrahman (2012: 157) kelompok model pengolahan informasi adalah salah suatu kelompok model pembelajaran yang lebih menitikberatkan pada aktivitas-aktivitas yang terkait dengan kegiatan proses atau pengolahan informasi untuk meningkatkan kapibilitas siswa melalui proses pembelajaran. Salah satu dari model pembelajaran pemrosesan informasi adalah model pembelajaran berpikir induktif, dalam penerapannya di kelas sangatlah merata pada siswa, karena penerapan model ini cocok pada semua tingkat kemampuan berpikir siswa dalam pembelajaran.

Menurut Uno (2011: 12) model berpikir induktif adalah suatu strategi mengajar yang dikembangkan untuk meningkatkan kemampuan siswa dalam mengolah informasi serta untuk mengembangkan keterampilan berpikir siswa.

Dengan mengembangkan memampuan berpikir siswa melalui penggunaan model induktif ini diharapkan siswa dapat belajar lebih baik lagi serta meningkatkan keterampilan dalam mengolah informasi-informasi dalam pembelajaran sastra di kelas.
Artikel ini akan mendeskripsikan penerapan model induktif dalam proses pembelajaran siswa dalam menggali nilainilai religius (ibadah, takwa, dan ikhlas), mengetahui kemampuan hasil belajar siswa dalam menggali nilai-nilai religius dalam Cerpen Robohnya Surau Kami Karya A.A. Navi, serta mengetahui faktor penghambat dalam penerapan model induktif dalam menggali nilai-nilai religius pada siswa kelas XI MAN Cianjur.

\section{METODE}

Penelitian dilaksanakan dengan penelitian tindakan kelas (PTK). Penelitian tindakan kelas merupakan suatu penelitian yang dilakukan oleh guru di dalam kelasnya sendiri melalui refleksi diri dengan tujuan untuk memperbaiki kinerja sebagai guru dalam pembelajaran di kelas agar tercapai hasil yang diinginkan.

Objek yang diteliti adalah kelas XI IPA 4 yang berjumlah 44 orang ( 12 laki-laki dan 32 perempuan). Penelitian dilaksanakan dalam 3 siklus dari tanggal 20 April - 27 Mei 2016. Setiap siklus melalui tahap perencanaan, pelaksanaan, pengamatan dan refleksi. Tindakan yang dilakukan untuk memecahkan masalah penelitian adalah penerapan model induktif yang mengikuti langkah-langkah Huda (2014:78) mengelompokkan sintak berpikir induktif ke dalam 3 tahapan, yaitu, tahap pertama adalah pembentukan konsep (guru mengalkulasi dan membuat daftar, siswa mengelompokan daftar, dan siswa membuat label dan kategori), tahap kedua adalah interpretasi data (siswa mengidentifikasi relasi-relasi penting antar kategori, mengeksplorasi relasi-relasi kategorial, dan membuat kesimpulan), dan tahap ketiga adalah tahap penerapan prinsip (siswa memprediksi konsekuensi, menjelaskan fenomena luar, meyusun hipotesis, siswa menjelaskan predikasi atau prediksi, dan siswa menguji kebenaran (verifikasi) prediksi). 
Ada 3 indikator yang ditetapkan sebagai acuan keberhasilan penelitian ini. Pertama, indikator proses pembelajaran siswa yaitu memperhatikan pembelajaran dan membangun kekompakan kelompok. Kedua, indikator hasil belajar siswa melalui tes siklus yang dilaksanakn setiap akhir siklus ditetapkan berdasarkan ketentuan Daya Serap Klasikal (DSK) 85\% mencapai kriteria ketuntasan minimal (KKM) 75. Ketiga, indikator faktor penghambat dalam penerapan model indukif dalam menggali nilia-nilai religus pada cerpen.

Sesuai data yang dikumpulkan instrumen yang digunakan adalah sebagai berikut. Teknik tes, angket, dan observasi. Tes digunakan untuk mengetahui tingkat kemampuan siswa dalam menggali nilai-nilai religius cerpen Robohnya Surau Kami karya A.A Navis, angket digunakan untuk mengetahui respon dan hambatan siswa dalam pembelajaran menggunkan model induktif, dan observasi digunakan untuk mengetahui aktivitas siswa selama pembelajaran berlangsung.

\section{HASIL DAN PEMBAHASAN}

\section{Siklus I}

Pembelajaran pada siklus I belum mencapai apa yang diharapkan peneliti, baik dari segi proses maupun dari segi hasil. Dari segi proses pembelajaran, ada beberapa siswa yang tidak memprhatikan pembelajaran, hal tersebut disebabkan masih ada beberapa siswa yang tidak memperhatikan pembelajaran, mereka malah asik mengobrol dengan teman sebangkunya. Dari jumlah keseluruhan 44 siswa, siswa yang kurang memperhatiakan pembelajaran sebanyak 15 siswa $(34,10 \%)$ sedangkan siswa yang memperhatikan pembelajaran sebanyak 29 siswa $(65,90 \%)$. Dari kekompakan dalam diskusi kelompok belum berjalan dengan baik dikarenakan ada beberapa siswa yang sibuk sendiri belum mampu bekerjasama atau diskusi dengan baik dengan kelompoknya. siswa kurang kompak dalam diskusi kelompok, dari jumlah keseluruhan 44 siswa, siswa yang kurang kompak dalam diskusi kelompok sebanyak 17 siswa $(38,63 \%)$ sedangkan yang kompak dalam diskusi kelompok sebanyak 27 siswa $(61,36 \%)$ hal ini sesuai dengan apa yang pengamat amati.

Sedangkan dari segi hasil belajar siswa, berdasarkan penilaian siklus I hasilnya dapat diketahui nilai rata-rata hasil belajar yaitu 68,64. Nilai tertinggi yaitu 85 (tuntas) sebanyak lima belas orang $(34,09 \%)$, sebanyak lima belas orang $(34,09 \%)$ mendapatkan nilai 70 (belum tuntas), nilai 55 (belum tuntas) sebanyak sembilan orang $(20,45 \%)$, dan nilai terendah yaitu 40 (belum tuntas) sebanyak lima orang $(11,37 \%)$. Jadi, berdasarkan kriteria ketuntasan maksimal (KKM) di MAN Cianjur yaitu 75, dan berdasarkan indikator keberhasilan yang ditetapkan, yaitu $85 \%$ atau lebih siswa mencapai kriteria ketuntasan maksimal (KKM) 75, baru 34,09\% siswa mendapat nilai mencapai KKM 75 dalam tes menggali nilainilai religius kategori nilai ibadah cerpen Robohnya Surau Kami karya A.A Navis.

Dari hasil siklus I banyak siswa yang belum mencapai nilai KKM yang ditentukan di sekolah dari hasil belajar siswa, dari 44 orang siswa baru 15 orang yang sudah mencapai KKM. Jadi, untuk meningkatkan hasil belajar siswa, peneliti melanjutkan pada siklus II, pada siklus II peneliti harus mengatur strategi untuk membuat siswa lebih memahami tentang nilai-nilai religius dalam cerpen dengan menggunakan model induktif.

\section{Siklus II}

Di dalam proses pembelajaran siklus II ada peningkatan dari siklus I. Pada siklus II dapat dilihat bahwa keadaan siswa ketika proses pembelajaran berlangsung, yaitu berkurangnya siswa yang tidak memperhatikan. Hal ini ditunjukan oleh sikap siswa ketika pembelajaran berlangsung mereka mulai antusias dalam pembelajaran. Dari segi proses pembelajaran, pada siklus II berkurangnya siswa yang kurang 
memperhatikan ketika proses pembelajaran berlangsung dibandingkan siklus I, dari jumlah keseluruhan 44 siswa, siswa yang kurang memperhatiakan pembelajaran sebanyak 11 siswa (25\%) sedangkan siswa yang memperhatikan pembelajaran sebanyak 33 siswa (75\%). Begitu pun dengan kekompakan kelompok pada siklus II mengalami peningkatan dibandingkan siklus I. Pada siklus II kekompakan kelompok mulai terjalin dan berjalan dengan baik, hanya ada beberapa siswa yang berbicara di luar materi dengan teman di sebelahnya tanpa memperdulikan kelompoknya. Dari jumlah keseluruhan 44 siswa, siswa yang kurang kompak dalam diskusi kelompok sebanyak 14 siswa $(31,82 \%)$ sedangkan siswa yang kompak dalam diskusi kelompok sebanyak 30 siswa $(68,18 \%)$ hal ini sesuai dengan apa yang pengamat amati.

Sedangkan dari segi hasil belajar siswa, berdasarkan penilaian siklus II hasilnya dapat diketahui nilai rata-rata hasil belajar yaitu 77,16. Nilai tertinggi yaitu 100 (tuntas) sebanyak empat orang $(9,10 \%)$, sebanyak dua puluh orang $(45,45 \%)$ mendapatkan nilai 85 (tuntas), sebanyak tiga belas orang $(29,54 \%)$ mendapatkan nilai 70 (belum tuntas), dan nilai terendah yaitu 55 (belum tuntas) sebanyak lima orang $(15,91 \%)$. Jadi, berdasarkan kriteria ketuntasan maksimal (KKM) di MAN Cianjur yaitu 75, dan berdasarkan indikator keberhasilan yang ditetapkan, yaitu $85 \%$ atau lebih siswa mencapai kriteria ketuntasan maksimal (KKM) 75, baru 54,55\% siswa mendapat nilai mencapai KKM 75 dalam tes menggali nilainilai religius kategori nilai takwa cerpen Robohnya Surau Kami karya A.A Navis.

Dari hasil siklus II banyak siswa yang belum mencapai nilai KKM yang ditentukan di sekolah dari hasil belajar siswa, dari 44 orang siswa baru 24 orang yang sudah mencapai KKM. Jadi, untuk meningkatkan hasil belajar siswa, peneliti melanjutkan pada siklus III, pada siklus III peneliti harus mengatur strategi untuk memaparkan materi dengan detail dan membuat perhatian siswa fokus pada pembelajaran yang sedang berlangsung dengan menggunkan model induktif.

\section{Siklus III}

Di dalam proses pembelajaran siklus III ada peningkatan dari siklus I dan II. Pada siklus III dapat dilihat bahwa keadaan siswa ketika proses pembelajaran berlangsung, yaitu hanya sedikit siswa yang kurang memperhatikan. Hal ini ditunjukan oleh sikap siswa ketika pembelajaran berlangsung mereka antusias dalam pembelajaran. Dari segi proses pembelajaran siklus III sudah mencapai target. Dari jumlah keseluruhan 44 siswa, siswa yang kurang memperhatiakan pembelajaran sebanyak 6 siswa $(13,64 \%)$ sedangkan siswa yang memperhatikan pembelajaran sebanyak 38 siswa $(86,36 \%)$. Begitu pun dengan kekompakan kelompok pada siklus III mengalami peningkatan dari siklus I dan siklus II. Pada siklus III kekompakan kelompok terjalin dengan baik, hanya ada sedikit siswa yang berbicara di luar materi dengan teman di sebelahnya tanpa memperdulikan kelompoknya. Dari jumlah keseluruhan 44 siswa yang kurang kompak dalam diskusi kelompok sebanyak 5 siswa $(11,36 \%)$ sedangkan siswa yang kompak dalam diskusi kelompok sebanyak 39 siswa $(88,64 \%)$ hal ini sesuai dengan apa yyang pengamat amati.

Sedangkan dari segi hasil belajar siswa, berdasarkan penilaian siklus II hasilnya dapat diketahui nilai rata-rata hasil belajar yaitu 91,82. Nilai tertinggi yaitu 100 (tuntas) sebanyak dua puluh empat (54,54\%), sebanyak enam belas orang $(36,36 \%)$ mendapatkan nilai 85 (tuntas), dan nilai terendah yaitu 70 (belum tuntas) sebanyak empat orang $(9,10 \%)$. Jadi, berdasarkan kriteria ketuntasan maksimal (KKM) di MAN Cianjur yaitu 75, dan berdasarkan indikator keberhasilan yang ditetapkan, yaitu $85 \%$ atau lebih siswa mencapai kriteria ketuntasan maksimal (KKM) 75, sudah melampaui nilai KKM dan indikator ketuntas $85 \%$. Ada 90,90\% siswa mendapat nilai mencapai KKM 
75 dalam tes menggali nilai-nilai religius kategori nilai ikhlas cerpen Robohnya Surau Kami karya A.A Navis.

Setelah dilakukan pengolahan dan analisis terhadap data hasil penelitian, maka pada bagian ini akan dibahas mengenai hasil dan temuan penelitian. Proses pembelajaran di kelas dan hasil belajar siswa pada siklus I, II, dan III.

Di dalam proses pembelajaran siklus I masih belum mencapai indikator yang ditetapkan. Ketidaktercapaian indikator keberhasilan pada siklus I ini disebabkan perhatian siswa ketika proses pembelajaran berlangsung masih ada beberapa siswa yang kurang memperhatikan, hal ini ditunjukan oleh sikap siswa ketika pembelajaran berlangsung mereka kurang antusias dalam pembelajaran. Dari hasil data yang telah diperoleh untuk perhatian siswa dalam pembelajaran di kelas pada siklus I, yang tidak memperhatikan pembelajaran dapat dilihat dari 44 siswa hanya 15 siswa $(34,10 \%)$ yang tidak memperhatikan pembelajaran, sedangkan dari 44 siswa ada 29 siswa (65,90\%) yang memperhatiakan pembelajaran. Berbeda dengan siklus I, terjadi peningkatan pada siklus II dari 44 siswa hanya 11 siswa (25\%) yang tidak memperhatikan pembelajaran, sedangkan dari 44 siswa ada 33 siswa (75\%) yang memperhatiakan pembelajaran. Pada siklus III pun terjadi peningkatan dari siklus II, pada siklus III dari 44 siswa hanya 6 siswa $(13,64 \%)$ yang tidak memperhatikan pembelajaran, sedangkan dari 44 siswa ada 38 siswa $(86,36 \%)$ yang memperhatiakan pembelajaran.

Dari hasil data yang telah diperoleh untuk kekompakan kelompok dalam pembelajaran tiap pada siklus, siswa yang tidak kompak pada pembelajaran di kelompok dapat dilihat pada siklus I dari 44 siswa hanya 17 siswa $(38,63 \%)$ yang tidak kompak pada diskusi kelompok, sedangkan dari 44 siswa ada 27 siswa $(61,36 \%)$ yang kompak pada diskusi kelompok. Berbeda dengan siklus I, terjadi peningkatan pada siklus II dari 44 siswa hanya 14 siswa $(31,82 \%)$ yang tidak kompak pada diskusi kelompok, sedangkan dari 44 siswa ada 30 siswa $(68,18 \%)$ yang kompak pada diskusi kelompok. Pada siklus III pun terjadi peningkatan dari siklus II, pada siklus III dari 44 siswa hanya 5 siswa $(11,36 \%)$ tidak kompak pada diskusi kelompok, sedangkan dari 44 siswa ada 39 siswa $(88,6 \% 4)$ yang kompak pada diskusi kelompok.

Dari hasil data yang telah diperoleh untuk observasi terhadap guru di kelas ketika proses pembelajaran nilai yang diperoleh dari pertemuan pertama adalah 2 dikategorikan cukup dan pertemuan kedua adalah 3 dikategorikan baik, nilai rata-rata yang diperoleh dari aktivitas guru di kelas pada siklus I adalah 2 dan dikategorikan cukup. Terjadi peningkatan pada siklus II dari hasil data yang telah diperoleh untuk pembelajaran di kelas ketika proses pembelajaran nilai yang diperoleh guru pada siklus II dari pertemuan pertama pertama adalah 3 dikategorikan baik dan pertemuan kedua adalah 3 dikategorikan baik, nilai rata-rata yang diperoleh dari aktivitas guru di kelas pada siklus II adalah 3 dan dikategorikan baik.

Dan peningkatan pun terjadi pada siklus III dari hasil data yang telah diperoleh untuk pembelajaran di kelas ketika proses pembelajaran nilai yang diperoleh pada siklus III mengalami peningkatan dari siklus I dan II, pertemuan pertama adalah 4 dikategorikan sangat baik dan pertemuan kedua adalah 4 dikategorikan sangat baik, nilai rata-rata yang diperoleh dari aktivitas guru di kelas pada siklus III adalah 4 dan dikategorikan sangat baik.

Dari hasil data yang telah diperoleh untuk observasi terhadap siswa di kelas ketika proses pembelajaran nilai yang diperoleh dari pertemuan pertama adalah 2 dikategorikan cukup dan pertemuan kedua adalah 2 dikategorikan cukup, nilai rata-rata yang diperoleh dari aktivitas siswa selama pembelajaran di kelas pada siklus I adalah 2 dan dikategorikan cukup. Terjadi peningkatan 
pada siklus II dari hasil data yang telah diperoleh untuk pembelajaran di kelas ketika proses pembelajaran nilai yang diperoleh guru pada siklus II dari pertemuan pertama pertama adalah 3 dikategorikan baik dan pertemuan kedua adalah 3 dikategorikan baik, nilai rata-rata yang diperoleh dari aktivitas siswa selama pembelajaran di kelas pada siklus II adalah 3 dan dikategorikan baik.

Dan peningkatan pun terjadi pada siklus III dari hasil data yang telah diperoleh untuk pembelajaran di kelas ketika proses pembelajaran nilai yang diperoleh pada siklus III mengalami peningkatan dari siklus I dan II, pertemuan pertama adalah 4 dikategorikan sangat baik dan pertemuan kedua adalah 4 dikategorikan sangat baik, nilai rata-rata yang diperoleh dari aktivitas siswa selama pembelajaran di kelas pada siklus III adalah 4 dan dikategorikan sangat baik.

Untuk hasil belajar siswa selama tes siklus dalam menggali nilai-nilai religius pada Robohnya Surau Kami menggunkan model pembelajaran induktif mengalami peningkatan pada setiap siklusnya. Untuk siklus I rata-rata hasil belajar siswa 68,64 pencapaian pada siklus I masih kurang dariharapan karena hanya beberapa orang yang memenuhi KKM di MAN Cianjur, sebab keadaan siswa ketika proses pembelajaran berlangsung masih ada beberapa siswa yang kurang memperhatikan, serta tidak aktif dalam menulis materi pembelajaran yang sedang berlangsung, dan hanya ada beberapa yang bertanya, hal ini ditunjukan oleh sikap siswa ketika pembelajaran berlangsung mereka kurang antusias dalam pembelajaran.

Pada siklus II nilai rata-rata siswa meningkat dari siklus I menjadi 77,16 . Peningkatan ini terjadi karena di dalam proses pembelajaran siklus II dapat dilihat bahwa keadaan siswa ketika proses pembelajaran berlangsung, yaitu berkurangnya siswa yang kurang memperhatikan, serta siswa mulai aktif bertanya dan menulis materi pembelajaran. Hal ini ditunjukan oleh sikap siswa ketika pembelajaran berlangsung mereka mulai antusias dalam pembelajaran.

Pada siklus III terjadi peningkatan dari siklus II yaitu nilai rata-rata siswa 91,82. peningkatan ini terjadi dalam proses pembelajaran siklus III dapat dilihat bahwa keadaan siswa ketika proses pembelajaran berlangsung, yaitu hanya sedikit siswa yang kurang memperhatikan, serta siswa aktif bertanya dan menulis materi pembelajaran. Hal ini ditunjukan oleh sikap siswa ketika pembelajaran berlangsung mereka antusias dalam pembelajaran. Pembelajaran pada siklus III kebanyakan siswa tidak mengalami kesulitan sehingga merupakan siklus terakhir dari rencana penelitian kelas ini. Berdasarkan hasil analisis, hal-hal yang perlu dilakukan guru dalam pembelajaran ini adalah memberikan arahan kepada siswa bagaimana cara menggali nilai-nilai religius pada cerpen supaya lebih mudah dipahami.

Untuk mengetahui faktor penghambat dalam penerapan model induktif, peneliti menggunakan angket. Angket berkenaan dengan respon siswa terhadap pembelajaran dan hambatan dalam pembelajaran menggunakan model induktif diungkap melalui angket tertutup. Setelah mengikuti pembelajaran menggali nilai-nilai religius menggunakan model pembelajaran induktif, berdasarkan angket yang terkumpul diperoleh data tentang respon belajar siswa yang beraneka ragam dan tercermin dalam berbagai aspek seperti berikut ini.

Dari hasil analisis angket di atas dapat disimpulkan bahwa penerapan model pembelajaran induktif terhadap pembelajaran menggali nilai-nilai religius pada cerpen sangat menyenangkan, mudah memahami pembelajaran dan sudah tepat penerapannya dalam pembelajaran bahasa Indonesia di kelas. Dan untuk faktor penghambat dari hasil analisis angket dapat disimpulkan bahwa penerapan model pembelajaran induktif terhadap pembelajaran menggali nilai-nilai religius pada cerpen membuat siswa mudah mencari dan memahami nilai-nilai religius 
pada cerpen serta menentukan kategori nilai religius pada cerpen setelah guru menerapkan model pembelajaran induktif selama proses pembelajaran berlangsung.

\section{SIMPULAN}

Berdasarkan hasil pengumpulan dan pengolahan data penerapan model pembelajaran induktif dalam pembelajaran menggali nilai-nilai religius dalam cerpen Robohnya Surau Kami karya A.A Navis di kelas XI MAN Cianjur tahun 2015-2016 disimpulkan hal-hal sebagai berikut.

Proses pembelajaran menggali nilianilai religius pada cepren dengan menggunakan model pembelajaran induktif dapat disimpulkan tiap siklus ada peningkatan ke arah yang lebih baik yang diharapkan oleh peneliti dari siklus I ke siklus II, dan dari siklus II ke siklus III, jumlah siswa yang memperhatikan pembelajaran dari siklus persiklusnya bertambah, siswa yang memperhatikan pembelajaran pada siklus I ada 29 siswa $(65,90 \%)$ yang memperhatikan, pada siklus II ada 33 siswa (75\%) yang memperhatikan, begitu pula pada siklus III mengalami peningkatan, ada 38 siswa $(86,36 \%)$ yang memperhatikan pembelajaran. Kekompakan kelompok pun mengalami peningkatan tiap siklus, terjadi kekompakan di mana siswa hanya mengerjakan tugas yang diberikan guru, pada siklus I ada 27 siswa $(61,36 \%)$ yang kompak, pada siklus II ada 30 siswa $(68,18 \%)$ yang kompak, begitu pula pada siklus III ada 39 siswa $(88,64 \%)$ yang kompak.

Hasil belajar siswa dengan menggunakan model pembelajaran induktif dapat meningkatkan hasil belajar siswa dalam menggali nilai-nilai religius pada cerpen Robohnya Surau Kami karya A.A. Navis karena hasil belajar siswa setiap siklusnya meningkat. Pada siklus I nilai rata-rata siswa sebesar 68,64 lalu pada siklus II nilai siswa meningkat menjadi 77,16 pada siklus III nilai rata-rata siswa 91,82 serta sebagain besar siswa nilainya sudah melampaui KKM.

Sehubungan dengan kesimpulan di atas, disajikan saran-saran kiranya dapat memberikan masukan dalam pengembangan pembelajaran menggali nilai-nilai religius pada cerpen dengan dengan model pembelajaran induktif.

Penggunaan model pembelajaran induktif cocok diterapkan pada pembelajaran menggali nilai-nilai pada cerpen, karena dapat membuat proses pembelajaran di kelas menjadi efektif dan hasil belajar siswa jadi meningkat.

Untuk peneliti yang lain yang sebentar lagi akan menjadi pengajar, penelitian tindakan kelas dapat dikembangkan dalam pelaksanaan pembelajaran setelah menjadi seorang pengajar sebab tujuan penelitian tindakan kelas yaitu untuk meningkatkan sesuatu hal yang bermasalah dilingkungan pembelajaran.

\section{DAFTAR PUSTAKA}

Aunurrahman. 2012. Belajar dan Pembelajaran. Bandung: Alfabeta.

Huda, Miftahul. 2014. Model-model Pengajaran dan Pembelajaran. Yogyakarta: Pustaka Pelajar.

Sanjaya, Wina. 2010. Strategi Pembelajaran. Jakarta: Kencana.

Uno, Hamzah B. 2011. Model Pembelajaran. Jakarta: Bumi Aksara. 